\title{
The right to self-representation before International Criminal Tribunals, while not absolute, should only be denied in limited circumstances
}

\author{
Paul BassetT \\ BCL, LLM, UnIVERSITy College DubLin
}

\begin{abstract}
$\underline{\text { Abstract }}$
One of the most controversial aspects of the International Criminal Tribunals (ICTs) and the International Criminal Court (ICC) concerns the right to self-representation. Many defendants have sought to use the trial as a stage on which to challenge the legitimacy of the court and to play to the crowd in their own home states. As a result, the various ICTs have sought to place limitations on the accused's right to selfrepresentation. The recent amendment to the Statute of the Supreme Iraqi Criminal Tribunal (SICT) is an example of this. This evolution raises questions concerning the effect such limitations may have on the overall fair trial rights of the accused. This article argues that there is a need to establish a guaranteed right of self-representation, provided the accused adheres to an objective set of conditions placed on the right. Such conditions should be confined to those strictly necessary to ensure the integrity of the court. Such a move would allow the court to gain some much needed legitimacy while at the same time deny defendants the ability to turn the court into a political stage.
\end{abstract}

\section{Introduction}

$\mathrm{O}$ ne of the most controversial aspects of the ICTs and the ICC concerns the right to self-representation. Many defendants have sought to use the trial as a stage on which to challenge the legitimacy of the court and to address the public in their own home states. Faced with disruptive and obstructionist behaviour, the various ICTs have sought to place limitations on the accused's right to self-representation. The amendment to fair trial rights in the Statute of the SICT is an example of this. Article 19(4)(d) provides certain minimum guarantees to the accused but the right to self-representation is conspicuous by its absence. ${ }^{1}$

For some this is a logical and sensible development, considering the problems encountered in tribunals such as the International Criminal Tribunal for the former Yugoslavia (ICTY) with disruptive defendants, including in the cases of Milosevic ${ }^{2}$ and Seselj. ${ }^{3}$ However, this development raises questions concerning the effect such limitations

1 Unofficial translation of revised Statute, available at www.law.case.edu/saddamtrial/documents/ ist_statute_offcialenglish.pdf. Article 19(4)(d) provides that the accused is entitled to the following minimum guarantees: "To be tried in his presence, and procure legal counsel of his choosing; to be informed of his right to ask for legal assistance in case he does not have sufficient means to pay for it; and of his right to receive assistance that allows him to procure legal counsel without financial burden."

2 Prosecutor v Milosevic IT-02-54-Misc.1: Milosevic.

3 Prosecutor v Seselj IT-03-67-R77.2: Seselj (contempt) issues on 24 July 2009. 
may have on the overall fair trial rights of the accused. In particular; is there a right to selfrepresentation in international criminal proceedings and what limitations should be placed on that right?

This article argues that, while there is a need to place limitations on the right to selfrepresentation, these limitations should be confined to those strictly required to protect the integrity of the court and the fair trial rights of the accused. It is important to recognise the distinction between objective fair trial standards required and the concept of autonomy for the accused. It will be argued that the court can ensure a fair trial for a self-representing accused through the innovative use of amici curiae and standby counsel while still affording the accused the desired level of autonomy over their own defence.

It is contended that there is a need to establish the right to self-representation based on a set of objective conditions. Counsel should only be assigned against the will of the accused where the conditions placed on self-representation are violated. Such conditions would give the desirable level of certainty and fairness to the manner in which the right is qualified. Crucially, these conditions would also deny the accused the opportunity to portray the decision to assign counsel as an arbitrary example of victor's justice. Such a move would allow the court to gain some much needed legitimacy while at the same time deny defendants the ability to turn the court into a political stage.

\section{Right of self-representation in international law}

The basis for the right to self-representation has been the subject of much debate. In Milosevic, Judge May stated that the right to self-representation is a matter of customary international law. ${ }^{4}$ This position is supported by Markovic. ${ }^{5}$ The right to self-representation in criminal proceedings is recognised under Article 14(3)(d) of the International Covenant on Civil and Political Rights (ICCPR) and Article 6(3)(c) of the European Convention on Human Rights (ECHR). Article 14(3)(d) of the ICCPR has been incorporated into the statutes of the ICTY, ${ }^{6}$ the International Criminal Tribunal for Rwanda (ICTR) ${ }^{7}$ and the Special Court for Sierra Leone (SCSL). ${ }^{8}$ Self-representation is also provided for in Article $67(1)(d)$ of the Rome Statute of the ICC.

The various ICTs to date have placed a heavy reliance on US Supreme Court jurisprudence when dealing with the right to self-representation. The US Supreme Court has always placed great emphasis on protecting the rights and freedoms of the individual from unwarranted intrusion on the part of the state. Markovic argues that the US Supreme Court views the right to self-representation as a bulwark against judicial paternalism. ${ }^{9}$ The US Supreme Court has given the right to self-representation constitutional status. ${ }^{10}$ In Farreta v California the Supreme Court stated that:

the defendant and not his lawyer or the state, will bear the personal consequences of a conviction. It is the defendant, therefore, who must be free personally to decide whether in his particular case counsel is to his advantage. ${ }^{11}$

\footnotetext{
4 M Scharf, "Self-representation in international criminal justice" (2006) 4(1) International Criminal Justice 31.

5 M Markovic, "In the interests of justice? A critique of the ICTY trial court's decision to assign counsel to Slobodan Milosevic" (2004-05) 18 Georgetown Journal of Legal Ethics 947.

6 Article 21(4)(d).

7 Ibid.

8 Article 17(4)(d).

9 Markovic, "In the interests of justice?", n. 5 above, p. 954.

10 Faretta v California 422 US 806 (1975).

11 Faretta v California 422 US 806, 834 (1975).
} 
This decision was expressly considered by the ICTY Trial Chamber in the Milosevic case when considering the accused's right to self-representation. ${ }^{12}$ The ICTR also relied heavily on US jurisprudence when considering the issue of self-representation. In Prosecutor $\mathrm{v}$ Barayagwiza, the Trial Chamber, when deciding on the appointment of standby counsel stated "this solution has been tried and tested in the United States, and has been proved to be an effective and appropriate procedure to assist the proper administration of justice". 13

The right to self-representation is not universal. In France, the presence of a lawyer is required before the Cour d'Assises, a court with jurisdiction over serious criminal offences. ${ }^{14}$ Germany also requires an accused to be represented by counsel when charged with a serious criminal offence. ${ }^{15}$ Additionally, the Supreme Court of India stated that the fairness of a trial may adversely be affected where a self-represented defendant cannot adequately follow proceedings. ${ }^{16}$ Scharf concludes that on this basis the right to selfrepresentation cannot be considered a matter of customary international law. ${ }^{17}$

Clearly, the customary law status of the right to self-representation is in some doubt. However, in contrast to the legal systems mentioned above, the ICTs and the ICC are primarily adversarial in nature. The right to self-representation has been applied in adversarial legal systems to a much greater extent. The incorporation of Article 14(3)(d) ICCPR into the statutes of the ad hoc tribunals and the express provision for selfrepresentation in the Rome Statute establishes that there is a presumptive right in ICTs to self-representation. ${ }^{18}$ As it is expressly provided for, self-representation must be considered the rule, making its derogation the exception. As such, exceptions from the fair trial rights of the accused should not be permitted except where strictly required.

\section{Fair trial rights}

\section{AUTONOMY V FAIR TRIAL STANDARDS}

The dominant rationale applied by the different ad hoc tribunals when restricting the right of self-representation has been that it is necessary in the interests of justice. ${ }^{19}$ In Barayagwiza, the ICTR held that, due to the adversarial nature of the proceedings, it was essential in the interests of justice that the accused should have legal counsel to ensure an effective defence at his trial. ${ }^{20}$ This was later applied in Norman by the SCSL where the Trial Chamber held that self-representation would result in the judges having to take a proactive role in the accused's defence to ensure a fair trial. ${ }^{21}$ In Seselj, the ICTY Trial Chamber's reasons for imposing counsel included the interests of justice and the complicated nature

12 Prosecutor $\mathrm{v}$ Milosevic IT-02-54-T: Trial Chamber reasons for decision on the prosecution motion concerning assignment of counsel, 4 April 2003, para. 18.

13 Barayagwiza ICTR 97-19-T, Gunawardana J concurring (citing Faretta 422 US 806 (1975)).

14 V Dervieux, "The French system" in M Delmas-Marty and J R Spencer (eds), European Criminal Procedures (Cambridge: CUP 2002), pp. 218, 231; The French Code of Criminal Procedure, G L Kock and R S Frase (trans.), with an introduction by R S Frase (Littleton CO: F B Rothman 1988).

15 See Strafprozeßordnung (Criminal Procedure Code), Article 140, available online at www.iuscomp.org/gla/ statutes/StPO.htm.

16 Scharf, "Self-representation", n. 4 above, p. 33.

17 Ibid. p. 38.

18 Milosevic IT-02-54-AR73.7: decision on interlocutory appeal of the Trial Chamber's decision on the assignment of defense counsel, Appeals Chamber, 1 November 2004, s. 9.

19 G Boas, The Milosevic Trial: Lessons for the conduct of complex international criminal proceedings (Cambridge: CUP 2007), p. 215.

20 Ibid.

21 Scharf, "Self-representation", n. 4 above , p. 37. 
of the proceedings. ${ }^{22}$ Bassiouni makes the argument that the right to self-representation is intended to complement the right to counsel rather than be a substitute for it. ${ }^{23} \mathrm{He}$ states that the court should impose counsel on the accused where it is necessary in the interests of justice. This balancing test is supported by Sluiter and Jorgensen. ${ }^{24}$

The manner in which the ICTs have restricted the right to self-representation is inconsistent with the "interests of justice" rationale expressed above. The practice of assigning standby counsel to the accused does not remedy the problems identified in Barayagmiza ${ }^{25}$ and Norman. ${ }^{26}$ In Milosevic, the ICTY Appeals Chamber permitted the accused to retain the primary role in the presentation of his defence despite the assignment of standby counsel. ${ }^{27}$ This meant that Milosevic was still making the strategic decisions regarding the conduct of his defence. Before counsel was imposed in Norman, as a result of disruptive behaviour, the accused was given strategic control over the presentation of the defence case with a standby counsel assigned. ${ }^{28}$ Therefore, the accused's perceived lack of expertise will still have a significant impact on the presentation of their case.

Another difficulty with the reasoning of the various tribunals is that the interests of justice concept is very vague. Boas claims the court should confine itself to the issue of fair trial rights in its reasoning. ${ }^{29}$ The court has an obligation to vindicate the fair trial rights of the accused. However, it is essential that the court recognises that one of the central components of the accused's overall right to a fair trial is autonomy over the defence. In Milosevic, the ICTY held that the rights afforded under ICTY Statute Article 21(4)(d), including the right to defend oneself in person or through legal assistance, were merely elements of the overarching requirement of a fair trial. ${ }^{30}$ While this is true, the fact that it is included as one of the requirements places an obligation on the court to vindicate that right as much as possible. Markovic makes the argument that the right to self-representation was created precisely to avoid the type of judicial paternalism evident in Norman. ${ }^{31}$ The US Supreme Court has stated that, as the accused is the person who will suffer the sanctions of any conviction, the accused should be allowed to decide whether counsel is to their advantage in any case. ${ }^{32}$ In Milosevic, the prosecution argued that, where an issue arose between the accused and counsel as to what was in the best interests of the accused, counsel's judgment would prevail. ${ }^{33}$ Such a position is a clear violation of the accused's right

22 M Sharf and C Rassi, "Do former leaders have an international right to self-representation in war crimes trials?” (2005) 20(3) Obio State Journal on Dispute Resolution 31-2.

23 M C Bassiouni, "Human rights in the context of criminal justice: identifying international procedural protections and equivalent protections in national constitutions" (1993) 3 Duke Journal of Comparative and International Law 283-4.

24 G Sluiter, "Fairness and the interests of justice, illusive concepts in the Milosevic case" (2005) 3 Journal of International Criminal Justice 3; see also N Jorgensen, "The problem of self-representation at international criminal trials: striking a balance between fairness and effectiveness" (2006) 4(1) Journal of International Criminal Justice 64, p. 68.

25 Boas, The Milosevic Trial, n. 19 above, p. 227.

26 Ibid. p. 224.

27 Ibid. p. 219.

28 Scharf, "Self-representation", n. 4 above, p. 34.

29 Boas, The Milosevic Trial, n. 19 above, p. 232.

30 J Jackson, Autonomy and Accuracy in the Development of Fair Trial Rights, UCD Working Papers in Law, Criminology and Socio-Legal Studies, Research Paper No 09/2009 (Dublin: UCD 2009), p. 16.

31 Markovic, "In the interests of justice?", n. 5 above, p. 954.

32 Faretta v California 422 US 806, 834 (1975).

33 Jorgensen, “The problem of self-representation”, n. 24 above, p. 70. 
to present the defence of their choice. For this reason, it is essential that the imposition of counsel be seen as a measure of last resort.

It is also important for the legitimacy of international criminal justice that courts be seen to afford the accused the greatest degree of autonomy possible. The ICTY in particular suffers from the perception of being "victor's justice" in Serbia. The fact that Milosevic's right of self-representation was revoked two years into the trial, after his very strong performance as counsel, was seen as an attempt to silence him. Assigning counsel without any objective criteria to guide the court also gives the decision the appearance of the court favouring expediency over justice. Markovic argues that the decision to impose counsel on Milosevic would have severely affected the legitimacy of any conviction in the eyes of the Serbian public. ${ }^{34}$

Jackson claims that a trade-off is often necessary between those standards that emphasise an effective defence and those that accentuate the importance of individual autonomy. ${ }^{35}$ Thus far the various tribunals seem to have valued expediency and objective fair trial standards higher than the accused's right to present the defence of their choice. Considering the legitimacy problems faced by the international criminal justice system as a whole, it is necessary for the court to give effect to the autonomy of the accused to the greatest extent possible, without allowing the overall fair trial rights of the accused to be undermined. In the following section it will be argued that there are measures available to the court, short of assigning counsel, capable of achieving this.

\section{EQUALITY OF ARMS}

The principle of equality of arms is central to any consideration of the right to selfrepresentation. The statutes creating all the ad hoc tribunals and the Rome Statute oblige the courts to ensure that neither party is at a significant disadvantage in the presentation of their case. ${ }^{36}$ Scharf and Rassi argue that the inherent equality of arms defects resulting from self-representation necessitate the assignment of counsel. ${ }^{37}$ They believe the lack of experienced legal counsel makes an effective defence impossible. ${ }^{38}$

This argument overlooks certain measures available to ICTs that would allow them to ensure effective equality of arms while stopping short of denying the accused the right to self-representation. Regulation 119(2) of the Regulations of the Registry of the ICC states that the Registry is responsible for providing assistance to an accused who has chosen to exercise the right to self-representation. Jorgensen claims that the various statutes and the Rules of Procedure and Evidence establishing the ICC and the ad hoc tribunals provide the powers required to take such measures. ${ }^{39}$ One such measure is the assignment of standby counsel or legal associates.

Standby counsel is a form of expert assistant who aids the accused in their defence. Standby counsel should not strictly raise issues on their own initiative and it is primarily the responsibility of the accused to determine how to present the case. ${ }^{40}$ In McKaskle v Wiggins the US Supreme Court held that where a court appoints a standby counsel for this purpose, even against the will of the accused, no sixth amendment violation will be found. ${ }^{41}$ In

34 Markovic, "In the interests of justice?", n. 5 above, pp. 955-6.

35 Jackson, Autonomy and Accuracy, n. 30 above, p. 2.

36 ECHR, Ankerl v Switzerland, judgment of 23 October 1996, Reports 1996-V, pp. 1565-6, para. 38.

37 Scharf and Rassi, "Former leaders", n. 22 above, p. 25.

38 Ibid.

39 Jorgensen, “The problem of self-representation", n. 24 above, p. 1.

40 Ibid. p. 69.

41 McKaskle v Wiggins 465 US 168 (1984). 
McKaskle, the standby counsel provided the role of explaining courtroom procedure to the accused and relieved the judge of the burden of assisting the accused in his defence.

The ICTY, ICTR and the SCSL have all applied the standby counsel model when dealing with the complexities of self-representation. ${ }^{42}$ Depending on the requirements of the case, standby counsel can be more or less intrusive on the accused's management of the case. ${ }^{43}$ In Seselj, the ICTY provided for the use of standby counsel. ${ }^{44}$ In departing from an earlier decision of the court in Milosevic, the Trial Chamber held the right to self-representation or representation through legal counsel was "not an either or relationship" and that standby counsel could assist the accused. ${ }^{45}$ In Seselj, the Trial Chamber outlined the duties of standby counsel. It expressly likened the role to a legal assistant for the accused. ${ }^{46}$ The standby counsel was to assist the accused in preparing documents for the court and to be present to assist the accused during the trial, although the accused would retain control over the presentation of the case. In Norman, the Trial Chamber of the SCSL held that, in the circumstances, the right to self-representation could only be permitted on the basis that the accused would be assisted by counsel, acting in the capacity of standby counsel. ${ }^{47}$ Another possibility is to allow the accused to communicate with legal associates. This was provided for in Milosevic. 48 Although the Trial Chamber never defined the role of "legal associate", it provided the accused with an avenue to prepare his defence effectively. 49

In its report on the Milosevic trial, Human Rights Watch argued that all self-representing defendants should be afforded some level of assistance from qualified legal counsel. . $^{50}$ Human Rights Watch believes that this would allow for much more effective presentation of a defence by the accused. If implemented, this would allow the court to ensure that the equality of arms within the trial process is maintained and, at the same time, give effect to the accused's right to self-representation provided under Article 14(3)(d) of the ICCPR and Article 67(1)(d) of the Rome Statute.

Another measure available to the court to ensure that the overall fairness of the trial is maintained is by extending the role of the amici curiae. An amicus curiae is a "friend of the court" and a position from which legal counsel, although not strictly a party to the proceedings, can make submissions to the court on areas of expertise, perspectives and fairness. The role of amicus curiae is provided for by rule 74 of the ICTY, the SCSL and the ICTR Rules of Procedure and Evidence and rule 103 of the ICC Rules of Procedure and Evidence. The ICC permits the amicus participation at any stage of the proceedings. ${ }^{51}$ The range of issues upon which the court may accept submissions is within the Trial Chamber's discretion. ${ }^{52}$

42 Boas, The Milosevic Trial, n. 19 above, pp. 61-62.

43 Jorgensen, “The problem of self-representation", n. 24 above, p. 69.

44 Prosecution v Vojislav Seselj IT-03-67PT: decision on prosecutor's motion for order appointing counsel to assist Vojislav Seselj with his defence, 9 May 2003.

45 Ibid para. 29.

46 Ibid para. 28.

47 Norman, Fofana and Kondewa SCSL-04-14-T: decision on the application of Samuel Hinga Norman for selfrepresentation under Article 17(4)(d) of the Statute of the Special Court, Trial Chamber, 8 June 2004, s. 26

48 Boas, The Milosevic Trial, n. 19 above, pp. 258-9.

49 Ibid.

50 S Darehshori, Weighing the Evidence. Lessons from the Slobodan Milosevic trials (New York: Human Rights Watch December 2006) www.hrw.org/en/reports/2006/12/13/weighing-evidence.

51 Boas, The Milosevic Trial, n. 19 above, p. 250.

52 Ibid. 
The role of amicus curiae was innovatively expanded in Milosevic. ${ }^{53}$ When the accused's request for self-representation was accepted, the Trial Chamber ordered the registrar to appoint amici curiae to enter submissions on aspects concerning the fairness of the proceedings and on issues that were open to the accused to challenge. Over the course of the trial, the role of the amici curiae expanded, becoming increasingly similar to a "de facto defence", even being entitled to submit appeals. ${ }^{54}$ The role of the amici curiae was a very substantial safeguard for the accused. They made submissions on a number of issues including objections to hearsay evidence being admitted against the accused, ${ }^{55}$ the manner of certain cross-examinations ${ }^{56}$ and, most importantly, entered a motion for judgment of acquittal of the accused. ${ }^{57}$

Another advantage of the use of amici curiae providing a role similar to a de facto defence is that they are not bound by the same ethical obligations to obey the client's instructions as an assigned defence counsel would be. ${ }^{58}$ An amicus curiae is not a representative of the accused and the duty of the amicus is to the court rather than to the accused. Such a duty to an uncooperative accused could adversely affect the way the defence is presented, due to the code of Professional Conduct for Defence Counsel. ${ }^{59}$ Additionally, in the event that the accused is unable to continue to represent him or herself the court can assign counsel who has been involved in the trial from the beginning to act as defence counsel.

Zapala is critical of this evolution in the amicus curiae role. ${ }^{60}$ Two of his criticisms deserve analysis. Firstly, he states that judges should not need assistance in ensuring a fair trial. $^{61}$ While correct in theory, the history of the ad hoc tribunals illustrates that, where defendant's insist on representing themselves, they are often more concerned with making political statements than defending the charges presented at trial. Although the fair trial rights provided in Article 14 ICCPR attach to the accused, it is the responsibility of the court to ensure that the trial is conducted in an overall fair manner. Therefore, it is important that the court takes the necessary measures to ensure that the fair trial rights of the accused are upheld. In addition, due to the complex nature of international criminal trials, judges are accustomed to having a large defence team to present arguments to them. It may be difficult for judges to perform their function when they are not in possession of all the relevant facts and arguments. Tunistra argues that the amici curiae can provide judges with a broader range of arguments to consider. ${ }^{62}$

Zapala also argues that in adversarial criminal trials there is no role for the amici curiae because the format provides for two parties contesting a charge before an impartial

53 Boas, The Milosevic Trial, n. 19 above, p. 251.

54 Prosecutor $\mathrm{v}$ Milosevic IT-02-54-T: decision granting request by the amici curiae for certification of appeal against a decision of the Trial Chamber, 25 September 2003.

55 Prosecutor v Milosevic IT-O2-54-T: amici curiae brief on rule 92 bis procedure, 20 February 2002.

56 Prosecutor $\mathrm{v}$ Milosevic IT-O2-54-T: response by the amici curiae to prosecution's motion for variation of an order of the Trial Chamber, 26 April 2002.

57 Prosecutor $\mathrm{v}$ Milosevic IT-O2-54-T: amici curiae motion for judgment of acquittal pursuant to rule 98 bis, 3 March 2004.

58 Darehshori, Weighing the Evidence, n. 50 above.

59 G Higgins, "The development of the right to self representation before the International Criminal Tribunals" in S Darcy and J Powderly (eds), Judicial Creativity at the International Criminal Tribunals (Oxford: OUP 2010), pp. 284-5.

60 S Zapala, Human Rights in International Criminal Proceedings (Oxford: OUP 2003).

61 Ibid. p. 63.

62 T Tunistra, "Assisting an accused to represent himself: appointment of amici curiae as the most appropriate option” (2006) Journal of International Criminal Justice 53. 
judge. ${ }^{63}$ While it is correct that adversarial criminal trials consist of the two-party conflict, the ICTs are hybrids of adversarial and inquisitorial systems and therefore are free to conduct the proceedings as they determine necessary. In addition, the role of an amicus curiae is not to defend an accused but to assist the court by enhancing its understanding of the issues before it.

The innovative use of the amicus curiae role in Milosevic is an excellent method of ensuring the overall fairness of the trial while, at the same time, vindicating the right to selfrepresentation. The criticisms of the expanded amicus curiae role outlined by Zapala are more theoretical than practical. Human Rights Watch stated that, due to the technical nature of international criminal trials, the role played by amicus curiae in challenging the more complicated aspects of cases can be an invaluable part of ensuring a fair trial for the accused. ${ }^{64}$ Given the very wide scope of amici curiae involvement provided for in the ICC and ad hoc tribunals' Rules of Procedure and Evidence, it is open to judges to apply the rules creatively to give effect to the rights of the accused where possible.

The two measures examined above are avenues that the various ICTs and the ICC could explore when adjudicating on motions to impose counsel on a defendant who is representing him or herself. Where less severe measures are available, the court should not derogate from the accused's right to self-representation on the basis that the fair trial rights of the accused are at risk. Any decision based on this rationale is ignoring the necessary element of individual autonomy of an accused over the presentation of the defence. The equality of arms principle can be satisfied by either assigning standby counsel to assist the accused, as in McKaskle, or by expanding the role, through judicial creativity, of the amicus curiae in the trial to something resembling a de facto defence.

\section{Necessary limits on the right to self-representation}

Thus far, the argument against restrictions on the right to self-representation has focused on the imposition of counsel on the basis that it is necessary to ensure a fair trial. Another set of issues arises where the court seeks to impose counsel on the accused due to disruptive behaviour during the trial, damaging the integrity of the court. It is contended that there is a need to establish an objective set of conditions and limitations placed on the accused prior to the commencement of the trial. The violation of such conditions would result in the accused losing the right to self-representation, as provided for in Faretta $\mathrm{v}$ California. ${ }^{65}$ Such conditions being put in place prior to the trial would have two distinct advantages. Firstly, it would act as a deterrent to a potentially disruptive accused. The knowledge that disruptive behaviour would result in counsel being imposed could be an important check on the accused in court. The second advantage is that, by clearly stating these conditions prior to any disruptive/insulting behaviour manifesting itself, the court is denying the accused the opportunity to portray him or herself as a martyr, silenced by the court to ensure a guilty verdict. The imposition of counsel should always be a last resort. However, the court must have the power to put in place a regime to ensure that the trial can proceed and that justice can be done. ${ }^{66}$ It is now necessary to examine those circumstances that would require denying the accused the right to self-representation.

63 Zapala, Human Rights, n. 60 above, p. 64.

64 Darehshori, Weighing the Evidence, n. 50 above.

65 (1975) 422 US 806.

66 Milosevic IT-02-54-T: reasons for decision on assignment of defence counsel, Trial Chamber, 22 September 2004, s. 33. 


\section{DISRUPTIVE/INSULTING BEHAVIOUR}

Many defendants seek to use the right to self-representation in international criminal trials as an opportunity to attack the legitimacy of the court and to address the public in their own states. The ICTs have been heavily influenced by American jurisprudence in the area of self-representation. The right to self-representation was given constitutional status in the United States Supreme Court decision of Faretta v California. ${ }^{67}$ However, a number of US courts have determined that the defendant forfeits the right when he or she acts in a disruptive manner. ${ }^{68}$ In United States v Cauley, the accused was denied the right to selfrepresentation due to disruptive conduct in court. ${ }^{69}$ There was an identical ruling in United States v West where the accused's conduct was held to be an attack on the dignity of the court. ${ }^{70}$ In United States v Mack, the court held that the accused's right to self-representation was subject to the court's duty to maintain order during the trial. ${ }^{71}$

The ICTs have also considered this issue. Throughout the Milosevic trial, the accused engaged in political speeches and the brow-beating of witnesses during crossexamination. ${ }^{72} \mathrm{He}$ also failed to show the requisite respect for the judges conducting the trial. However, there are a number of measures available to a court in these circumstances aside from the revocation of the right to self-representation. The Rules of Procedure and Evidence could be used to limit counsel (or a self-representing accused) to matters at issue in the case during cross-examination. ${ }^{73}$ The problem with such a solution is that it may restrict the ability to cross-examine effectively, adversely affecting the overall fairness of the trial. An innovative solution to this low-level disruption is to place time limits on the parties' examinations of witnesses. Human Rights Watch has argued that such a position would result in less confrontation between the accused and the bench while still allowing the accused to use the time allocated as they wished. ${ }^{74}$ In Milosevic, this was applied to good effect, with the judges even suggesting fruitful areas of cross-examination to the accused. ${ }^{75}$

Where disruptive or insulting behaviour brings the integrity of the trial into disrepute it is important that any international tribunal should have the power to revoke the right to self-representation. In Seselj, the accused routinely insulted other officers of the court and even attempted to violate witness protection measures in his cross-examinations. ${ }^{76}$ The Trial Chamber referred to the European Court of Human Rights' (ECtHR) case of Saday $\mathrm{v}$ Turkey where counsel was imposed on the accused because of disruptive behaviour. ${ }^{77}$ The ECtHR stated that "personal verbal attacks against a judge may warrant sanction if they create an atmosphere detrimental to the orderly functioning of justice". ${ }^{78}$ The Jankovic trial

67 (1975) 422 US 806.

68 Jackson, Autonomy and Accuracy, n. 30 above, p. 14.

69697 F2d 486, 491 (2nd Cir 1983).

70877 F2d 281, 286 (4th Cir 1989).

$71362 \mathrm{~F} 3 \mathrm{~d}$ at 601.

72 Scharf, "Self-representation", n. 4 above, p. 31.

73 Rule 140(2)(c) of the ICC Rules of Procedure and Evidence limits the issues that can be raised by the parties during cross-examination.

74 Darehshori, Weighing the Evidence, n. 50 above.

75 Ibid.

76 M Milanovic, "The arrest and impending trial of Radovan Karadzic?" (2009) 58 International and Comparative Law Quarterly 212, p. 217.

77 Saday v Turkey, App. No 32458/96.

78 M Ellis, "Saddam trial: challenges to meeting international standards of fairness with regard to the defense" (2006-08) 39(1) Case Western Reserve Journal of International Law 176-7. 
faced similar problems due to the intentionally disruptive conduct of the accused. ${ }^{79}$ If such a disruptive defendant was afforded an absolute right to self-representation it would be inconsistent with other Articles of the Rome Statue or the statutes creating the ad hoc tribunals. ${ }^{80}$ Where measures such as time limits and enforcement of the Rules of Procedure and Evidence are not sufficient to ensure the integrity of the proceedings, the court must have the power to revoke the accused's right to self-representation. If respectful behaviour in court was an express condition on the right to self-representation the court would have the power to take decisive action to restore order.

\section{OBSTRUCTING/FRUSTRATING THE PROCEEDINGS}

One situation where the court must have the power to assign counsel is where the accused does not wish to be represented by counsel purely to frustrate the trial. In United States v Harris, the court rejected the defendant's request for self-representation. ${ }^{81}$ The court found that the defendant refused to acknowledge the authority of the court, showed disrespect for the court, and that his attempts to proceed unrepresented were meant to disrupt the court. ${ }^{82}$

In Prosecutor v Barayagwiza, the accused sought the withdrawal of his counsel, citing reasons of lack of competence and loyalty. ${ }^{83}$ The ICTR Trial Chamber examined the right to self-representation as articulated in the statute but held, by referring to international jurisprudence, that the right is not absolute. The Trial Chamber, in rejecting the motion for withdrawal, held that the accused was seeking to obstruct the proceedings by not permitting an effective defence to be put forward. The accused in this instance was not seeking to represent himself at the trial. His intention was not to enter any defence, in an attempt to damage the legitimacy of any verdict reached against him.

The SCSL also established that counsel could be assigned to an accused who refused to recognise the court. In Gbao, the defence sought a motion that the accused be afforded his right not to have counsel representing him. ${ }^{84}$ The Appeals Chamber held that this was a motion to have counsel withdrawn and not a motion for self-representation. The reason for the accused's request was to obstruct the proceedings. ${ }^{85} \mathrm{On}$ this basis the chamber rejected the appeal to have the defence counsel withdrawn.

The ICC and the ad hoc tribunals have a legitimate interest in ensuring that justice is done and that trials proceed. If the court was to allow the accused to frustrate the proceedings by refusing to participate in person or through counsel, the fairness of the proceedings would be adversely affected. The legitimacy of a verdict issued in absentia would be questionable and would allow the accused to portray him or herself as the victim of an unjust court. Therefore, where an accused is attempting to boycott the trial by entering no defence, the court should be allowed to assign defence counsel to ensure the fairness and legitimacy of the proceedings.

79 Ellis, "Saddam trial", n. 78 above.

80 Article 64(2) of the Rome Statute states that the Trial Chamber must conduct proceedings with due regard for the protection of victims and witnesses.

81317 F Supp 2d 542, 546 (DNJ 2004).

82 Scharf, "Self-representation", n. 4 above, p. 35.

83 Ibid. p. 36.

84 Boas, The Milosevic Trial, n. 19 above, pp. 225-6.

85 Ibid. 


\section{LATE REQUESTS FOR SELF-REPRESENTATION}

The third situation where ICTs have held that the accused's right to self-representation can be set aside is where the request is made after the commencement of the trial. The rationale behind this is linked to the issue of obstructing justice discussed above. In Krajisnik, the ICTY rejected the accused's request for self-representation. ${ }^{86}$ The chamber held that "the assertion of a right to self-representation will succeed or fail depending on the factual context" and that a relevant factor is the potential disruption to proceedings that selfrepresentation may cause. ${ }^{87}$ The chamber also referred to Faretta and held that the timing of a request for self-representation was a factor to take into account when considering what effect to give the right. Where such a request is made during the trial, the judge has a greater discretion to reject it as it may have a disruptive effect on the trial. In Norman, the accused's request for self-representation was made during the trial. ${ }^{88}$ In rejecting the request, the Trial Chamber found the fact that Norman did not state his intention to represent himself prior to the commencement of the trial was a factor that would allow a judge a greater discretion to deny an accused the right to self-representation. 89

The connection between a late request and perceived disruption to the trial was also evident in Ntabobali. ${ }^{90}$ In this case the court took into account that the accused was not attempting to disrupt the proceedings. The accused had volunteered to represent himself pending the assignment of new counsel. Despite amending the order to assign standby counsel the chamber allowed the accused to dispose of his counsel. ${ }^{91}$ This illustrates that where a request is made during the trial the likely disruption to the proceedings will be the determining factor for the court assessing the request. One of the conditions placed on the right to self-representation should be that any request is submitted to the court prior to the trial commencing to ensure that the proceedings are not significantly disrupted.

\section{HEALTH OF THE ACCUSED DISRUPTING THE TRIAL}

The most controversial circumstance where the accused's right to self-representation has been revoked is where ill health has prevented attendance at trial. In Milosevic, the accused's right to self-representation was revoked two years into the trial for this reason. ${ }^{2}$ His condition required that he reduce his workload to such a degree that the Trial Chamber could only sit three days a week. Although the Appeals Chamber modified the decision of the Trial Chamber and assigned standby counsel rather than imposing defence counsel on Milosevic, it did uphold the Trial Chamber decision that it was not an abuse of its discretion to assign counsel in the circumstances. The Appeals Chamber held that "the right may be curtailed on the grounds that a defendant's self-representation is substantially and persistently obstructing the proper and expeditious conduct of his trial". 93 The result of the decision was that Milosevic was permitted to present his case when physically capable.

This position was not followed in Seselj. The judgment, which in effect overruled Milosevic, held:

86 IT-00-39-A (2009).

87 Jorgensen, "The problem of self-representation", n. 24 above, p. 66.

88 Sam Hinga Norman SCSL-04-14-T: decision on the application of Samuel Hinga Norman for selfrepresentation under Article 17(4)(d) of the Statute of the Special Court, Trial Chamber, 8 June 2004, s. 32.

89 Scharf, "Self-representation", n. 4 above, p. 37.

90 Boas, The Milosevic Trial, n. 19 above, pp. 227-8.

91 Ibid.

92 Milosevic IT-02-54-T: reasons for decision on assignment of defence counsel, Trial Chamber, 22 September 2004.

93 Jackson, Autonomy and Accuracy, n. 30 above, p. 16. 
In light of the Appeals Chamber, and in the interests of justice of fairness to Seselj, the Appeals Chamber nullifies the opening of the proceeding in this case and orders that the trial restart. Due to the current health conditions of the accused, the Appeals Chamber orders that his trial should not open until such time as he is fully able to participate in the proceeding as a selfrepresented accused. ${ }^{94}$

The contradictory caselaw raises arguments on both sides. Jorgensen makes the point that the accused may perceive a greater degree of unfairness when the right to selfrepresentation is revoked on health grounds alone. ${ }^{95}$ Prior to Milosevic, there was no precedent for assigning counsel on the basis that the accused's health was affecting the proceedings. The Trial Chamber recognised that extensive research had not identified any jurisdiction where counsel had been assigned to an accused person because the defendant was unfit to conduct the case as the result of impaired physical health. ${ }^{96}$ The difficulty this creates is that the accused is losing the right to self-representation through no fault of their own. ${ }^{97}$ This affects the fairness of the proceedings. Markovic argues that the chamber should also have considered whether the accused was fit to stand trial if he was no longer fit to represent himself. ${ }^{98}$

Human Rights Watch believes that the health of the accused should be a factor in considering the right to self-representation. ${ }^{99}$ Accused individuals should have the condition placed on their right to self-representation from the beginning that they be able to attend court a minimum number of times per week. Had this condition been placed on Milosevic and Seselj from the beginning, it would have been less controversial for the court to impose counsel on the defence. The fact that the condition is placed on the accused from the beginning, even before any issue over the accused's health arises, would give the court's decision to impose counsel an increased sense of legitimacy and fairness. The court's obligation to conduct "fair and expeditious trials" also includes taking into account the interests of the victims and the public and of the defendants themselves in having an efficient trial process. The right to a fair trial, provided by Article 14 ICCPR and guaranteed by the Rome Statute in Article 67, attaches to the accused and not to the other parties to a trial. However, given the obligation on the court to ensure the expediency of the trial and the vindication of the fair trial rights of the accused, it is not unreasonable for the court to assign standby counsel in such a situation.

\section{Conclusion}

The right to self-representation is recognised as an element of the overall fair trial rights attached to the accused. While it is not an absolute right, any violation must be strictly necessary. If a trial is to be fair, it is essential that the accused be allowed to exercise the maximum degree of autonomy over their own case as possible. ICTs and the ICC should take whatever measures are reasonably available in the circumstances before revoking or denying the right to self-representation as a last resort. Higgins believes that it is only through creative judicial interpretation that the ICC and the ad hoc tribunals will be able to uphold the rights of the accused while at the same time ensuring a fair and expeditious

94 Boas, The Milosevic Trial, n. 19 above, p. 235.

95 Jorgensen, "The problem of self-representation", n. 24 above, p. 68.

96 Higgins, "The development of the right to self representation", n. 59 above, p. 258.

97 Ibid.

98 Markovic, "In the interests of justice?", n. 5 above, p. 954.

99

Darehshori, Weighing the Evidence, n. 50 above. 
trial. ${ }^{100}$ In particular, the expanded use of amici curiae, as in Milosevic, and standby counsel, as applied in Seselj, allow the court to ensure the overall fair trial rights of the accused are upheld while still allowing accused people to present their defence in the manner they choose. For this reason, Article 19(4)(d) of the SICT represents a regressive step in the fair trial rights afforded to defendants in international criminal trials.

However, limitations of the right to self-representation are required in some circumstances. Where an accused's behaviour is significantly disrupting the proper and expeditious conduct of the trial, the court has a legitimate interest in imposing counsel. If an objective set of conditions were placed on the exercise of the right it would give the court an objective basis to limit the right where the integrity of the trial was under threat. Such conditions would give the desirable level of certainty and fairness to the manner in which the right is qualified. This argument is supported by Higgins who believes that ICTs need to determine an objective threshold to be reached before counsel should be imposed on an accused. ${ }^{101}$ The advantages of establishing a set of conditions based on the arguments outlined in this article are clear. It would allow the international criminal law system to gain some much-needed legitimacy while at the same time it would deny defendants the ability to turn the court into a political stage. 
